$6 \% .2 / 23$ me (1) $I-10986$

SANDIA REPORT SAND83-0370 U Ùnlimited Release • UC-13

Printed March 1983

\title{
Compression Wave Studies in Oakhall Limestone
}

\author{
Dennis E. Grady
}

\section{Prepared by}

Sandia National Laboratories

Albuquerque, New Mexico 87185 and Livermore, California 94550

for the United States Department of Energy

under Contract DE-AC04-76DP00789

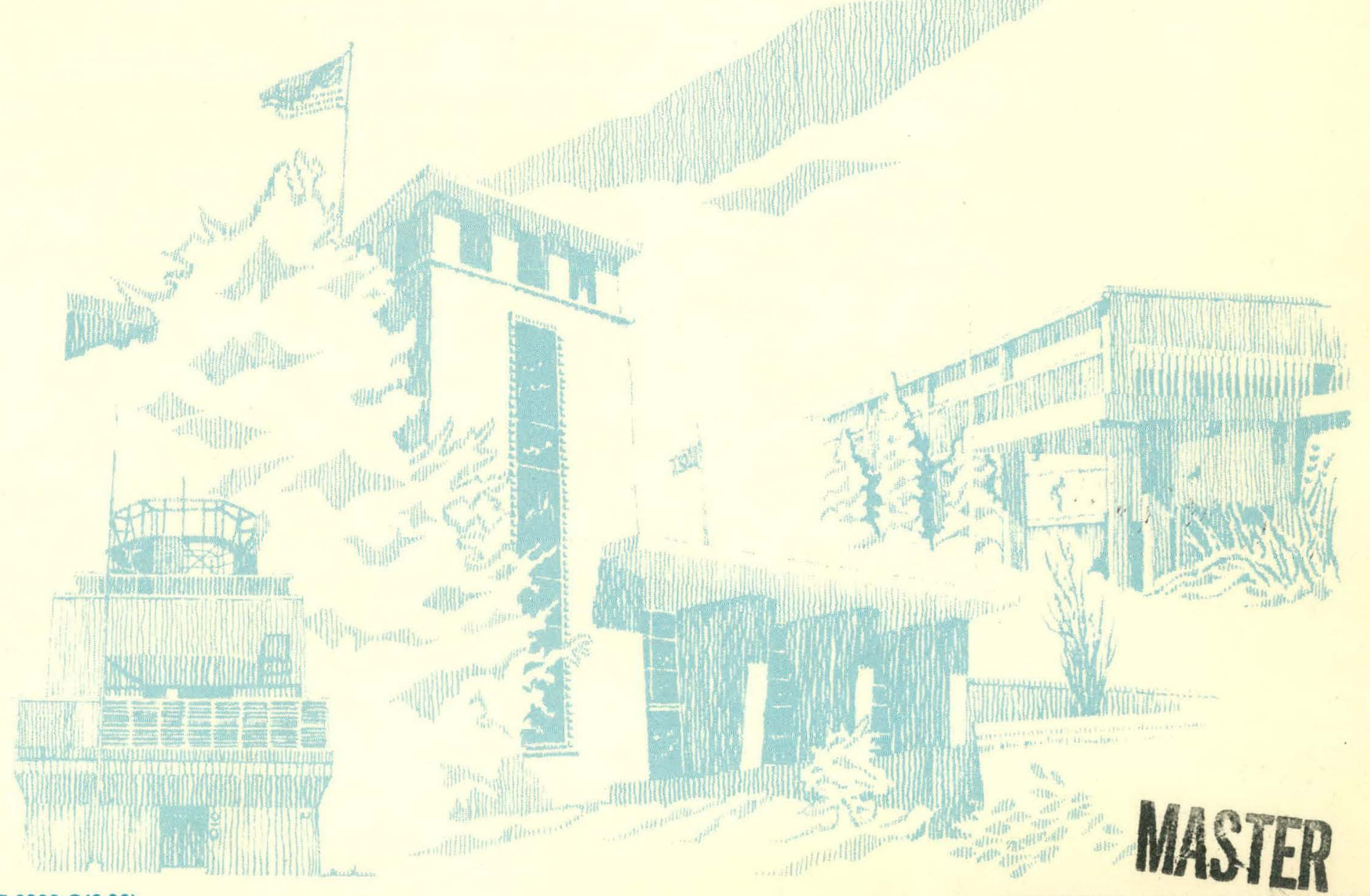




\section{DISCLAIMER}

This report was prepared as an account of work sponsored by an agency of the United States Government. Neither the United States Government nor any agency Thereof, nor any of their employees, makes any warranty, express or implied, or assumes any legal liability or responsibility for the accuracy, completeness, or usefulness of any information, apparatus, product, or process disclosed, or represents that its use would not infringe privately owned rights. Reference herein to any specific commercial product, process, or service by trade name, trademark, manufacturer, or otherwise does not necessarily constitute or imply its endorsement, recommendation, or favoring by the United States Government or any agency thereof. The views and opinions of authors expressed herein do not necessarily state or reflect those of the United States Government or any agency thereof. 


\section{DISCLAIMER}

Portions of this document may be illegible in electronic image products. Images are produced from the best available original document. 
Issued by Sandia National Laboratories, operated for the United States Department of Energy by Sandia Corporation.

NOTICE: This report was prepared as an account of work sponsored by an agency of the United States Government. Neither the United States Government nor any agency thereof, nor any of their employees, nor any of their contractors, subcontractors, or their euuluyees, makes any warranty, express or imnlied. or assimmes any legal liahility or raspongibility for the accuracy, completeness, or usefulness of any information, apparatus, product, or process disclosed, or represents that its use would not infringe privately owned rights. Reference herein to any specific commercial product, process, or seivice by trade name, trademark, manufacturer, or otherwise, does not necessarily constitute or imply its endorsement, recommendation, or favoring by the United States Government, any agency thereof or any of their mntrarters $\mathrm{nr}$ suhenntractors. The views and opinions expreosod horcin du not necessarily state or reflect those of the United States Government, any agency thereof or any of their contractors or subcontractors

Printed in the United States of America Available from

National Technical Information Service

U.S. Department of Commerce

5285 Port Royal Road

Springfield, VA 22161

NTIS price codes

Printed cony: A02

Microfiche copy: A01

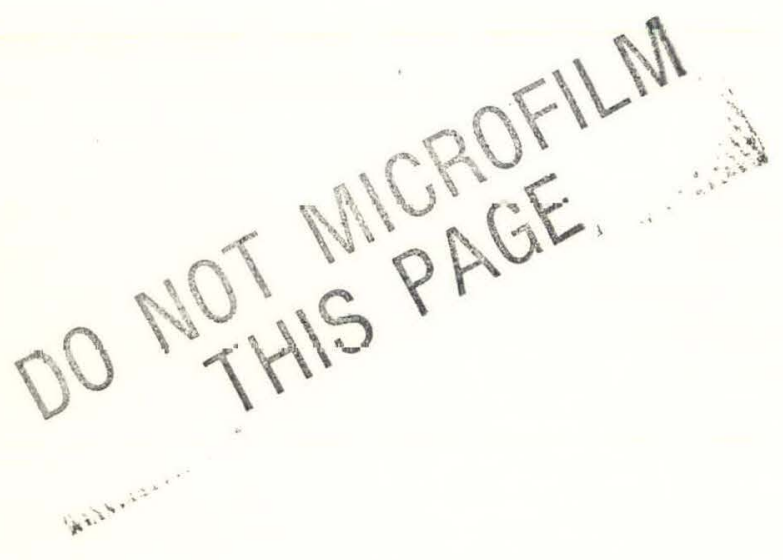


Distribution

Category UC-13

SAND83-0370

Unlimited Release

Printed March 1983

COMPRESSION WAVE STUDIES

IN OAKHALL LIMESTONE

D. E. Grady

Thermomechanical and Physical Division 1534

ABSTRACT

A series of 15 large amplitude (0-4.0 GPa) compression wave experiments have been performed on oakhall limestone using impact techniques. Time-resolved particle velocity profiles were determined with window laser interferometry. Three experiments were performed at each impact velocity on samples of difterent thickness and stress-strain hehavior was determined through Lagrangian analysis of the measured wave profiles. Two shock-induced phase transformations are observed within the range of the data. The first occurs within the elastic region of response and initiates a rarefaction shock wave on unloading. The second is characteristic of the more sluggish transformations observed in silicate rock. The present data have been used to demonstrate the importance of shear in shock-induced phase transformations.

\section{DISCLAIMER}

This report was prepared as an account of work sponsored by an agency of the United States Government. Neither the United States Government nor any agency thereof, nor any of their employees, makes any warranty, express or implied, or assumes any legal liability or responsihility for the accuracy, completerress, or usefulness of any information, apparatus, product. or process disclosed, or represents that its use would not infringe privately owned rights. Reference herein to any specific commercial product, process, or service by trade name, trademark, manufacturer, or otherwise does not necessarily constitute or imply its endorsement, recommendation, or favoring by the Unital Statcs Government or any agency therenf. The views and opinions of authors expressed herein do not necessarily state or reflect those of the United States Government or any agency thereof. 


\section{CONTENTS}

I. Introduction . . . . . . . . . . . . . . . . . 5

II. Experimental Procedures . . . . . . . . . . . . . . . 7

III. Experimental Data and Analysis . . . . . . . . . . . . . 9

IV. Discussion . . . . . . . . . . . . ......... . 21

References . . . . . . . . . . . . . . . . . 23 


\section{INTRODUCTION}

The work presented here is an extensive experimental study of the wave propagation characteristics of the calcite rock called Oakhall limestone. The experiments were completed in 1977 and the data reported in part with similar data on several other carbonate rocks in two publications 1,2 . A large portion of the data on this rock remained unpublished, however. With the recent intensification of needs for accurate model characterization of geological materials, and with emphasis on those undergoing rarefaction shock unloading due to dynamic phase transformation, it was considered useful to make available the complete set of data.

Therefore, this report provides a documentation of the one-dimensional wave propagation properties of Oakhall limestone to approximately $4.0 \mathrm{GPa}$. This rock was selected as representative of near zero porosity, fine grain limestone. The work contrasts with similar studies on Solenhofen limestone, 3 a porous calcite rock, vermont marble, 4 a coarse grain, metamorphosed calcite rock, and Blair dolomite, 5 a low porosity magnesiumcalcium carbonate rock. The present study focused primarily on the range covering dynamic failure and the calcite phase change which complicate response of this material.

Dynamic stress states were achieved with plate impact methods, and impact conditions are specified so that both loading and unloading behavior is determined. 


\section{EXPERIMENTAL PROCEDURES}

The experimental procedure used in the present study has been documented earlier; ${ }^{3}$ however, for completeness a brief summary is provided. The experimental methods used to investigate wave propagation properties under plate impact conditions are illustrated in Fig. 1. A $100 \mathrm{~mm}$ diameter light gas gun is used to impel flat-nosed aluminum projectiles. at the target. Projectiles are faced with thin plates of mechanically well-known impact material, which in turn are backed with low impedance solid foam. Fused quartz and 1060 aluminum were the standard impact materials used in the present study. Impact on the target material provides a step input stress wave in the sample material followed by an unloading wave originating at the impact plate-solid foam interface. Projectile velocities ranging from from 0.01 to $1.0 \mathrm{~mm} / \mu \mathrm{sec}$ can be controlled within about 28 and impact planarity can be maintained within 3 or 4 times $10^{-4}$ radians. The projectile velocity is measured by offset pins to within 0.28 and impact time at center-of-impact is measured to within about $10 \mathrm{~ns}$ using an offset impact fiducial pin and a planarity measurement with coplanar flush pins or a center of impact ribbon fiducial technique. 6

The sample specimen is backed with a laser window. Fused quartz was used in the current study of rock properties. The window material surface in contact with the sample surface is first vapor deposited with silver to provide a diffusely reflecting surface. Material velocity is continuously recorded through the complete loading and unloading response with diffuse velocity interferometry (VISAR).7

The series consisted of 15 tests performed at 5 different impact velocities. Sample thickness varied between 5 and $25 \mathrm{~mm}$. This provided for measurement of evolution of the wave from the initial square wave input and stress-strain behavior was determined by Lagrangian analysis methods. 8

The Oakhall limestone used in the present study. was provided by D. B. Larson of Lawrence Livermore National Laboratory and is the same material studied by Murri et al.9 The microstructure of oakhall limestone is finegrain micrite with a few larger recrystallized calcite grains. The density is $2700 \mathrm{~kg} / \mathrm{m}^{3}$ and the porosity is less than 0.58 . Measured longitudinal and shear wave velocities were $6.71 \mathrm{~km} / \mathrm{s}$ and $3.22 \mathrm{~km} / \mathrm{s}$, respectively. 


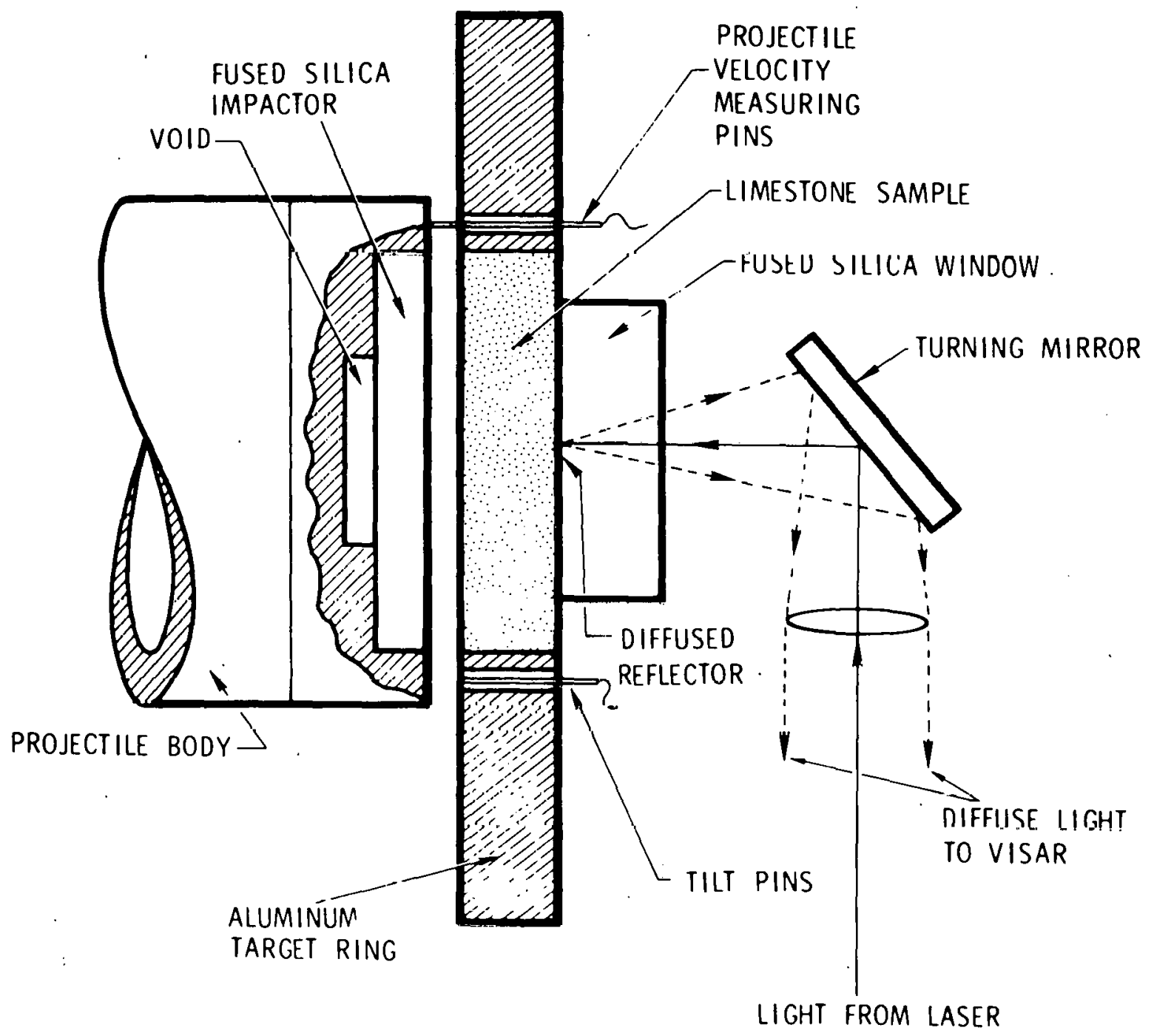

Figure 1. Impact target assembly including projectile, target material, laser window, and near target laser optics. 
A total of 15 impact experiments were successfully completed on oakhall limestone. Experiments were performed at 5 impact velocities, and 3 impact thicknesses were studied at each velocity level. A description of each impact experiment is provided in Table 1. Experimental data for each shot consist of oscilloscope traces of the two $90^{\circ}$ out of phase VISAR photomultiplier outputs which contain the sample-window material interface motion history. Impact time of arrival data are also provided on the same photomultiplier records. The oscilloscope traces of the VISAR data are reduced to digital information on a telereader system and stored on computer. The digital VISAR data are reduced to particle velocity profiles of the samplewindow interface history with a user interactive computer program developed by Barker. 10

Velocity profiles corresponding to the same impact velocity level are then scaled to correct for slight differences in impact velocity and impactor thicknesses. Since the window material is never an exact impedance match for the test material, a region of wave interaction is created in the test material near the sample-window interface, and the measured interface velocity profile is a distorted version of the input profile in the specimen. The extent of distortion depends on the difference in the constitutive properties of the window material and the unknown constitutive properties of the sample material. A user interaction computer program 8 was used which corrects the velocity profiles for impedance mismatch at the samplewindow interface and provides the loading and unloading stress-strain, stess-particle velocity and longitudinal moduli of the sample material.

The experimental data will be presented in this section in the following order: first, the initial arrival transit time data for all experiments will be presented. Second, the experimental profiles and constitutive behavior for each impact velocity level will be presented in order. Each impact level will be identified by the series number given in Table 1. T.ast., the composite stress-strain, stress-particle velocity and longitudinal moduli results will be presented for all of the data.

\section{First Arrival Velocity}

A velocity corresponding to first arrival of the stress wave at the measuring interface can he determined for each shot from the transit time from impact at the sample center to first arrival at the sample-window interface and the thickness of the sample specimen. Transit times were nhtained from 12 of the 15 tests. Distance-time plots of the first arrival data showed that the velocity was independent of propagation distance dind independent of the driving stress amplitude. A velocity of $6.57 \pm .07 \mathrm{Km} / \mathrm{s}$ was obtained for Oakhall limestone, which is 28 smaller than the measured ultrasonic velocity. In further analysis, all experimental wave profiles were alligned acccording to this velocity. 


\section{DESCRIPTION OF IMPACT EXPERIMENT}

\begin{tabular}{|c|c|c|c|c|c|c|c|}
\hline & $\begin{array}{l}\text { hot } \\
\text { No. }\end{array}$ & $\begin{array}{c}\text { Series } \\
\text { No. }\end{array}$ & $\begin{array}{c}\text { Impact } \\
\text { velocity } \\
\text { (km/sec) }\end{array}$ & $\begin{array}{c}\text { Impact } \\
\text { Material }\end{array}$ & $\begin{array}{l}\text { Impactor } \\
\text { Thickness } \\
\text { (mm) }\end{array}$ & $\begin{array}{c}\text { Sample } \\
\text { Thickness } \\
\text { (mm) }\end{array}$ & $\begin{array}{l}\text { Window* } \\
\text { Thickness } \\
\text { (mm) }\end{array}$ \\
\hline LS & 104 & 1 & 0.106 & $\mathrm{FQ}^{\star}$ & 3.246 & $5 . C 29$ & 19.1 \\
\hline LS & 105 & 1 & 0.116 & " & 3.239 & $10 . C 03$ & 19.1 \\
\hline LS & 106 & 1 & 0.113 & $"$ & 3.205 & $15 . C 24$ & 25.4 \\
\hline LS & 107 & 2 & 0.216 & $"$ & 3.068 & 4.986 & 19.1 \\
\hline LS & 108 & 2 & 0.212 & " & 3.231 & 9.985 & 25.4 \\
\hline LS & 109 & 2 & 0.208 & $"$ & 3.239 & 14.963 & 25.4 \\
\hline LS & 101 & 3 & 0.352 & $"$ & 3.165 & 5.966 & 19.1 \\
\hline LS & 102 & 3 & 0.355 & $"$ & 4.757 & $12 .(190$ & 25.4 \\
\hline LS & 110 & 3 & 0.352 & $"$ & 3.259 & $17 .(46$ & 25.4 \\
\hline LS & 111 & 4 & 0.619 & $"$ & 4.747 & 4.961 & 25.4 \\
\hline LS & 112 & 4 & 0.621 & " & 4.760 & 8.539 & 25.4 \\
\hline LS & 103 & 4 & 0.592 & $"$ & 4.768 & 11.930 & 25.4 \\
\hline LS & 113 & 5 & 0.691 & $\mathrm{Al}^{+}$ & 4.801 & $4 . \subsetneq 89$ & 25.4 \\
\hline & 114 & 5 & 0.691 & $"$ & 4.818 & $9 . C 50$ & 25.4 \\
\hline & 115 & 5 & 0.689 & $"$ & 4.798 & $13 .[73$ & 25.4 \\
\hline
\end{tabular}

* Fused Quartz, General Electric Dynasil-1000

+1060 Aluminum (dead sof.t) 
At the lowest projectile impact velocity of approximately $0.11 \mathrm{~km} / \mathrm{s}$ three tests were successfully completed with sample thicknesses of about 5 , 10, and $15 \mathrm{~mm}$ (see Table 1). In Fig. 2 the final particle velocity profiles, uncorrected for impedance differences between the fused quartz and the limestone, are displayed. The profiles shown differ slightly from the original VISAR record of the sample-window interface velocity in that the data are scaled to account for slight differences in impact velocity and the unloading wave was adjusted for slight differences in impactor thickness (see Table 1). In the Series 1 tests the low projectile velocities achieved were difficult to control and variations up to about \pm 48 resulted. In all higher velocity experiments projectile velocities were consistent within \pm 18 .

The profiles obtained in this series were at the lower end of applicability of the VISAR system. Approximately two-thirds of a light fringe was obtained from zero to peak particle velocity. Some noise was noted on the top of the profile and the beam intensity trace. We attributed this to the large calcite grains in the limestone samples.

Propagation properties at this stress level appeared to be predominantly elastic. There was some indication of rounding of the loading profile near the top of the wave which would suggest a finite steady-wave behavior, such as was observed, and attributed to dynamic crack effects, in Blair dolomite ${ }^{5}$ The unloading wave was dispersive, indicating some anelastic behavior. This could be attributed to a softening of the modulus on unloading due to crack opening. These details can be seen in the stress-strain, stressparticle velocity and wave velocity-stress plots, provided in Fig. 2 .

\section{Series 2 Data}

Projectile impact velocity for this series was $0.21 \mathrm{~km} / \mathrm{s}$. Sample thicknesses of approximately 5,10 and $15 \mathrm{~mm}$ were used for the three tests completed. The profiles obtained in this series are shown in Fig. 3 . In this series, departure from linear elastic wave propagation was observed. The loading wave breaks over at about $0.05 \mathrm{~km} / \mathrm{s}$ and is characterized by slower and dispersive wave propagation above this level. The unloading wave was less dispersive than observed in Series 1. The stress-strain, stress-particle velocity and wave velocity-stress curves for series 2 are also shown in Fig. 3.

\section{Series 3 Data}

The projectile impact velocity for this series was $0.35 \mathrm{~km} / \mathrm{s}$. Sample thicknesses were approximately 6,12 and $17 \mathrm{~mm}$. Profiles obtained in this series are shown in Fig. 4. A break in the loading wave profile was observed between 0.05 and $0.07 \mathrm{~km} / \mathrm{s}$, above which a dispersive ramp wave occurred. The unloading wave was nondispersive and propagated as a rarefaction shock wave. Wave attenuation was observed within the propagation range. The Series 3 curves for stress-strain, stress-particle velocity and wave velocity-stress are shown in Fig. 1 . 

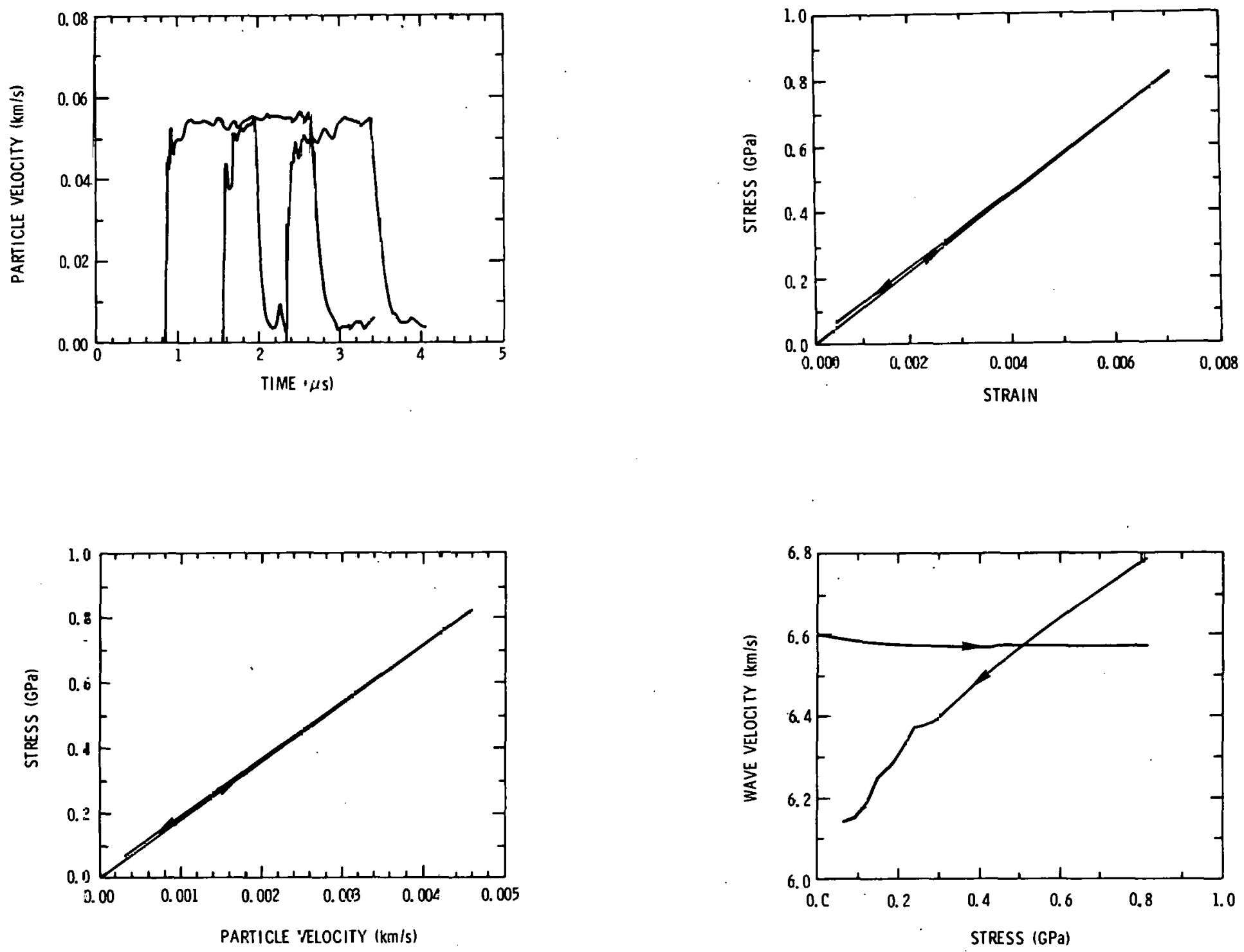

Figure 2. Wave profiles and constitutive properties for Series - test. 

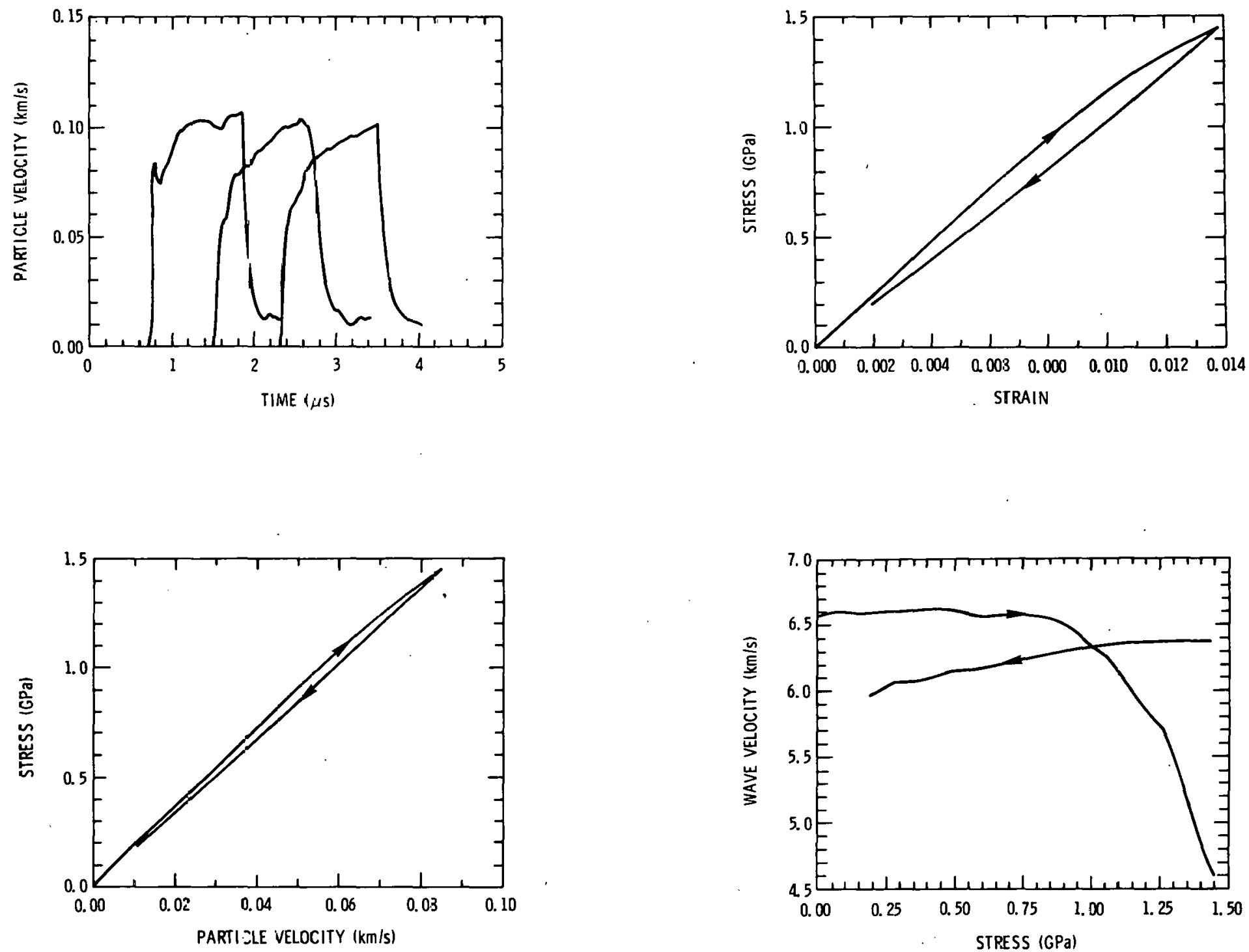

Figure 3. Wave profiles and constitutive properties for series 2 tests. 

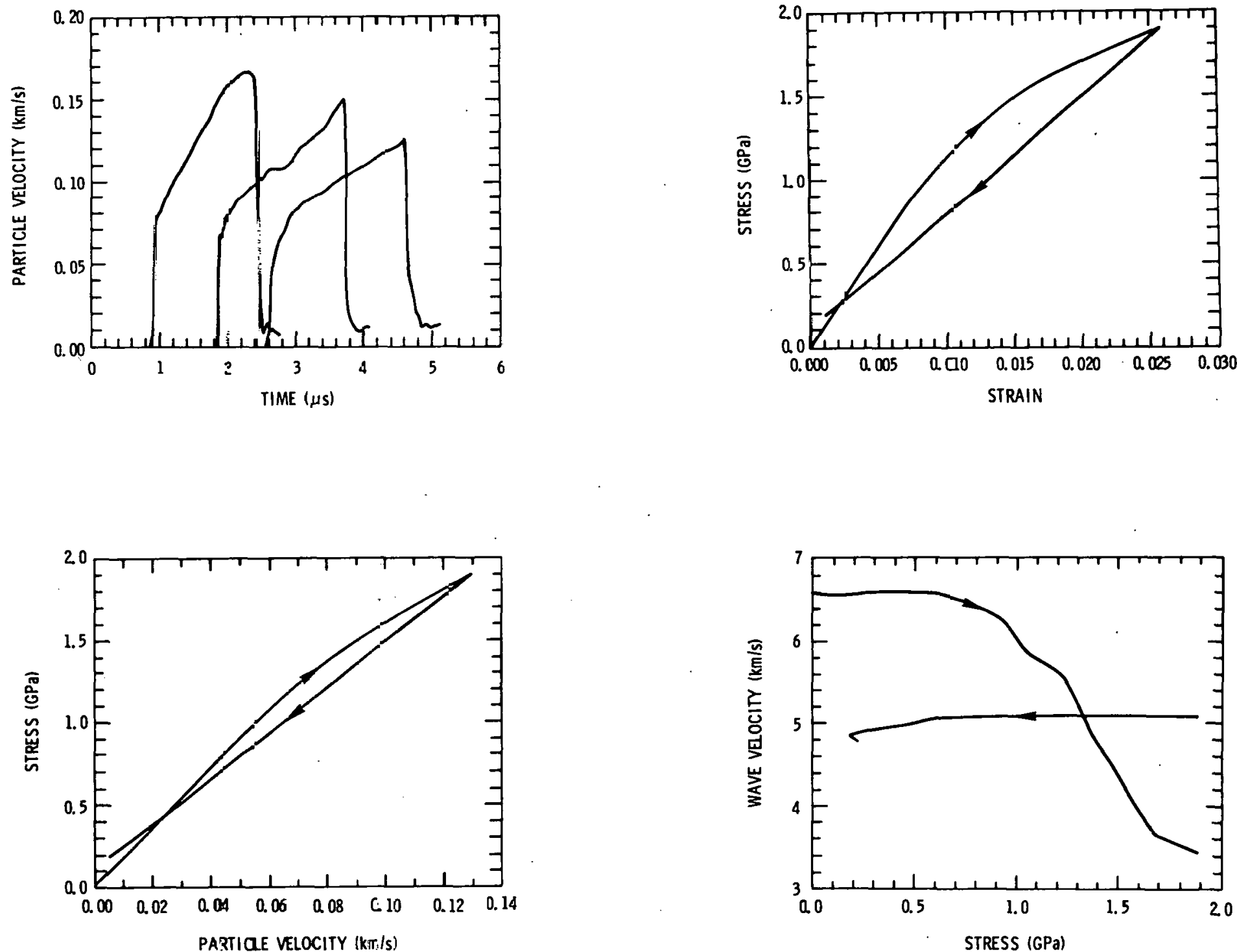

Figure: 4. Wave profiles and constitutive properties for Series 3 tests. 
The projectile velocity for this series was $0.62 \mathrm{~km} / \mathrm{s}$. Sample thicknesses were reduced to approximately $5,8.5$ and $12 \mathrm{~mm}$ for the Series 4 tests due to the wave attenuation effects observed in Series 3. Profiles obtained in this series are shown in Fig. 5. As can be seen, the profile complexity and dispersive properties have increased with the increased impact velocity. Initial loading occurred through an abrupt shock to approximately $0.07 \mathrm{~km} / \mathrm{s}$ followed by a ramp wave to about $0.14 \mathrm{~km} / \mathrm{s}$. Further loading, however, indicates the formation of a second shock wave. Unloading proceeds by a dispersive upper region followed by a rarefaction shock wave initiating at about $0.15 \mathrm{~km} / \mathrm{s}$. Again, wave attenuation occurs within the region of observation. The stress-strain, stress-particle velocity and wave velocitystress curves are shown in Fig. 5 .

\section{Series 5 Data}

The projectile impact velocity for this series was $0.69 \mathrm{~km} / \mathrm{s}$. Impact conditions for this series differed from all earlier series in that 1060 Aluminum was used as the impactor material rather than fused quartz. The purpose was to achieve a higher impact stress in the limestone samples. Sample thicknesses for this series were approximately 5, 9, and $13 \mathrm{~mm}$. In Fig. 6 the particle velocity profiles obtained in this series are shown. Material loading proceeds in three distinct regions; an initial shock wave, a ramp wave, and a final shock wave to peak amplitude. Unloading occurs by a dispersive wave and a rarefaction shock wave. Complete unloading is not achieved and the rarefaction shock velocity is considerably lower than in the Series 4 tests. Both observations can be accounted for by the higher impedance aluminum impactor. The stress-strain, stress-particle velocity and wave velocity-stress plots for the series 5 data are shown in Fig. 6 .

\section{Combined Results}

In this section the results from all five experimental series are repeated in combined plots for the purpose of comparison. In Fig. 7 we show the stress-strain and stress-particle velocity loading and unloading histories. Break over in the stress-strain curve due to material nonlinearity can clearly be seen between 1.0 and $2.0 \mathrm{GPa}$. A steepening of the Hugoniot (end points of the loading paths) is observed in the higher stress experiments. Unloading is characterized by hysteresis and dispersion. In Fig. 8 the wave velocity-stress curves for both loading and unloading are shown. In the loading wave velocity plot, material softening initiating at about $1.0 \mathrm{GPa}$ can be seen followed by a rapid reduction in velocity with stress. Higher loading wave velocity behavior corresponds to formation of a second shock wave. The unloading plot shows a low stress dispersive region, an intermediate stress region where rarefaction shocks form and a high stress, highly dispersive reglon. 

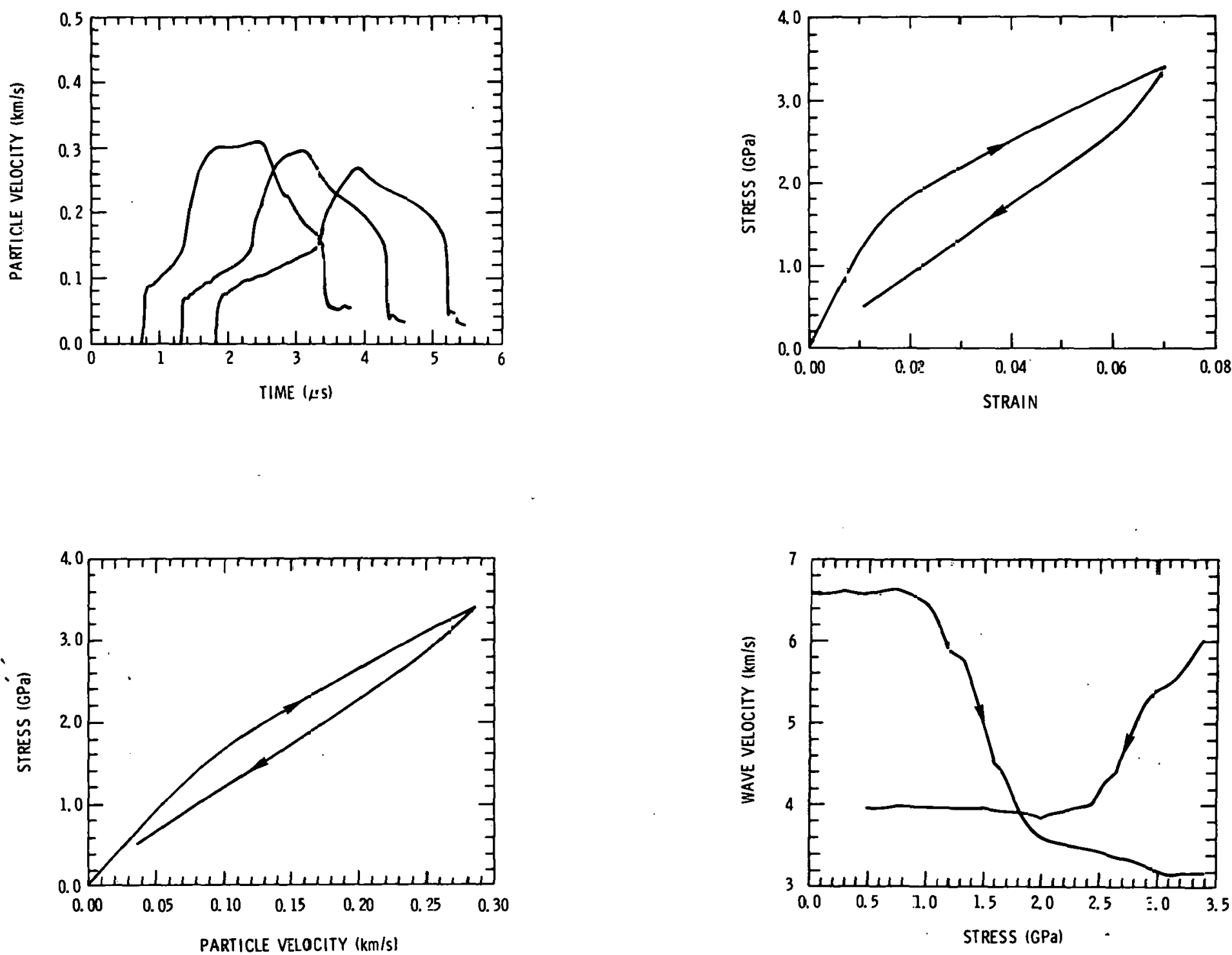

Figure 5. Wave profiles and constitu=ive properties for series 4 tests. 

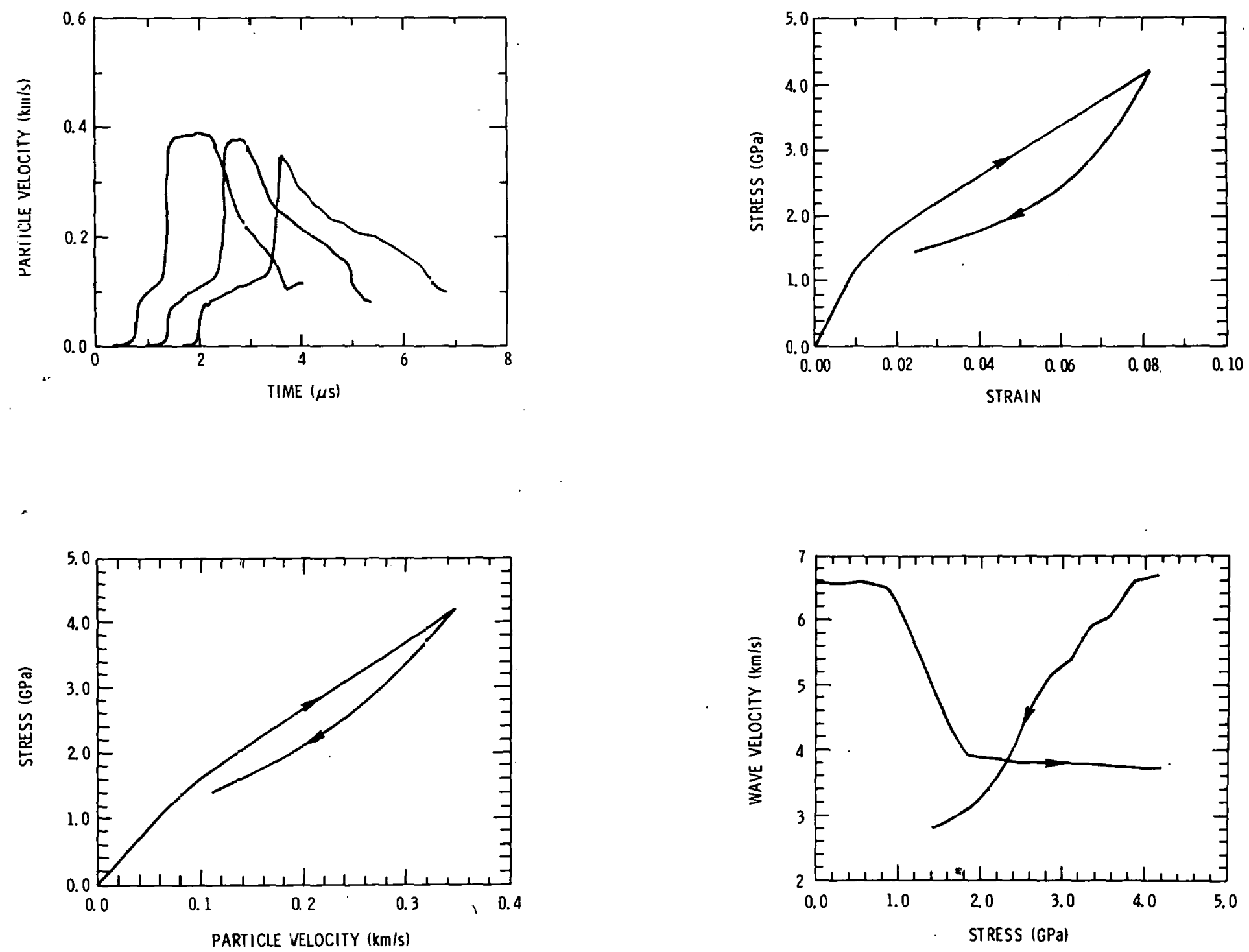

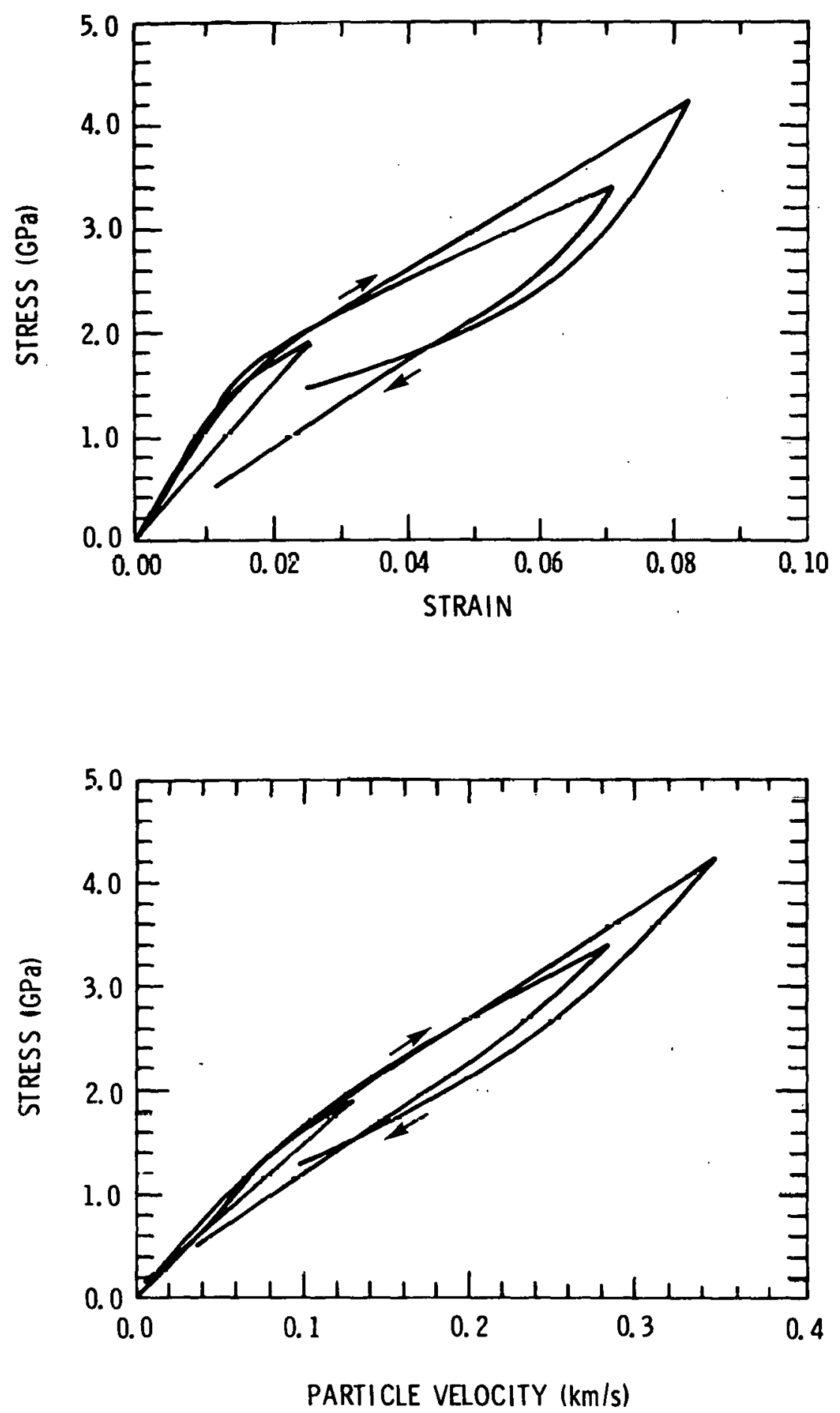

Figure 7. Combined stress-strain-particle velocity response for all five series. 

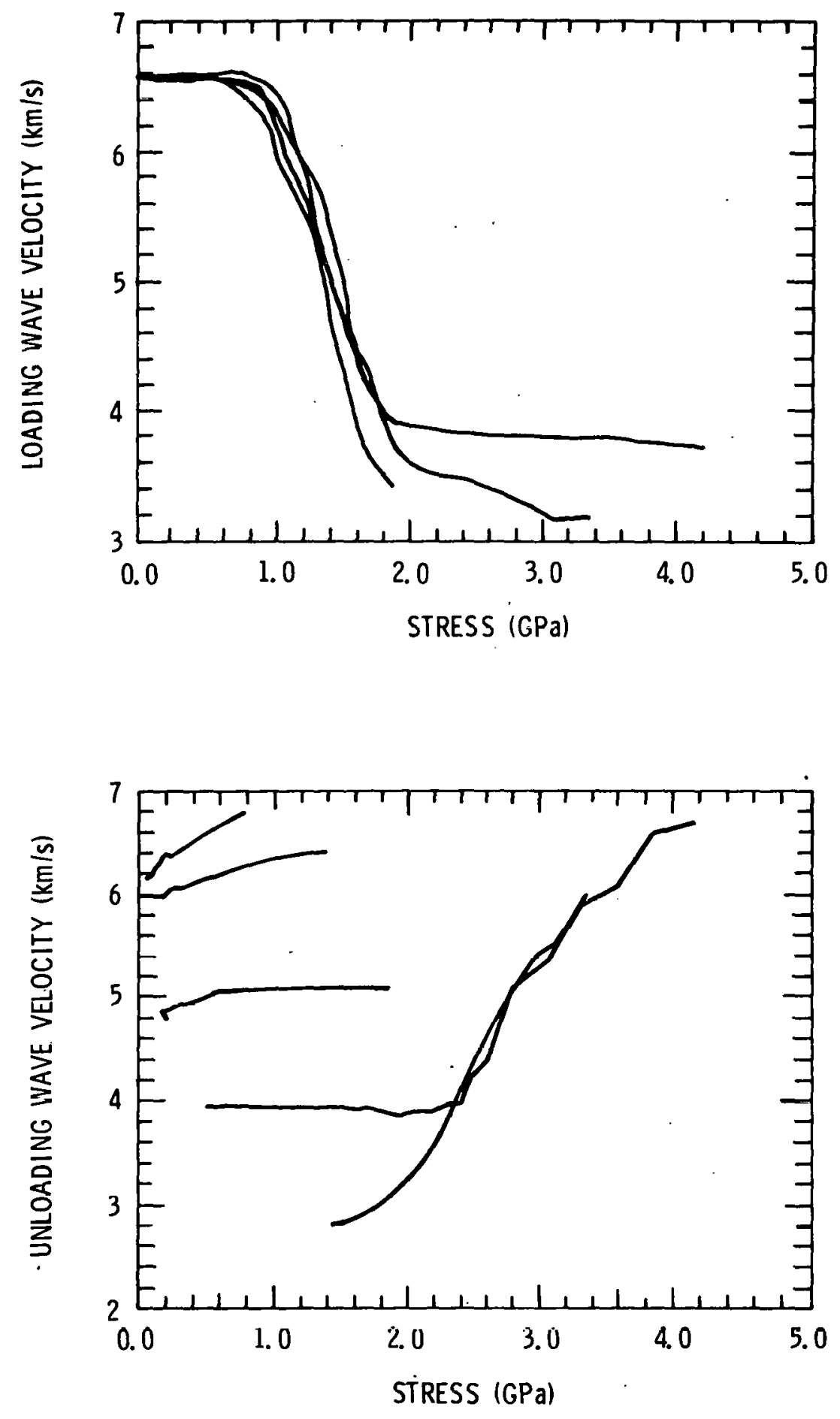

Figure 8. Loading and unloading wave velocity for all five series. 


\section{DISCUSSION}

The large-amplitude wave profiles measured in Oakhall limestone illustrate a striking complexity in structure not observed in most solids. When these data are compared with similar stress wave data on Solenhofen limestone and vermont marble, and a large body of static triaxial, hydrostatic and ultrasonic data on similar calcite rocks existing in the literature, a fairly clear picture of the mechanisms governing the high rate deformation of this material emerges. Extensive interpretation and analysis of these data have been performed and have revealed the relative importance of flow, fracture and phase transformation in the deformation process.1,2 These references should be consulted for a thorough discussion.

An important feature of the shock uniaxial strain response of Oakhall limestone relates to yielding or the Hugoniot elastic limit. A clear first wave is identified in the loading structure; however, it has been shown that the amplitude of this wave is not due to plastic flow or fracture but indicates onset of the first stress-induced phase transformation. The transformation apparently delays onset of irreversible deformation. Calculations have shown that the uniaxial strain response of Oakhall limestone is reversible until peak stress in excess of $2.0 \mathrm{Gpa}$ is achieved. 1 It appears that the first calcite transformation occurs within the region of elastic response of the material.

Within the range of the present data two shock-induced phase changes occur in Oakhall limestone. The first is identified as the displacive calcite I-II transition initiating at approximately $0.9 \mathrm{GPa}$ shock stress. This transformation proceeds over an appreciable stress range due to stress concentrating effects in the material and accounts for the ramp behavior following the initial elastic loading wave. Comparison of the present shock data with triaxial compression data has shown that this transformation is sensitive to the shear stress state in the material 2 and the modeling of nonhydrostatic phase transformation has focused on this result. ${ }^{11}$

A second transformation initiates at a shock stress of about $2.4 \mathrm{GPa}$ and can be observed as the second break in the loading wave of the series 4 profiles (Fig. 5). It is identified as the calcite II-III transformation and, in contrast to the calcite I-II transformation it is hysteretic and probably rate sensitive. Details of wave structure suggest that the II-III transition is similar to the reconstructive transformation in silicate rocks under shock compression. 1

The release wave behavior of Oakhall limestone shows no indication of elastic-plastic response. The initial velocity of the release wave in Series 3,4 and 5 has been compared with the elastic propertles of calcite III. The velocity is closer to bulk rather than longitudinal suggesting fluid-like rather than solid-like behavior, and is also characterlstic of the shockwave response of silicate rocks. 
The unique feature of the release wave in Oakhall limestone is the formation of a rarefaction shock. Although a rarefaction shock is predicted theoretically for a phase transforming material, it is not usually observed due to the finite rate of most transformations. Initiation of the rarefaction shock at approximately $1.5 \mathrm{GPa}$ is due to the displacive calcite I-II transition which proceeds readily on a shock wave time scale. Indications of the rarefaction shock are seen in all profiles of the top four series, but it is most clearly revealed in the profiles of series 4 .

The rarefaction shock velocity decreases with increasing shock amplitude as shown in the unloading wave velocities of Fig. 8. This velocity is not an intrinsic property of calcite but is determined by the total impact problem, including impactor material and foam backing the impactor. The rather diminutive rarefaction shock in series 5 is a consequence of the aluminum impactor, which resulted in a rather short Rayleigh line segment on release.

The sharpness of the rarefaction shock was unexpected and fast-sweeping oscilloscopes were focused on it in several experiments to determine the width, which compares well with a $0.05 \mu \mathrm{s}$ relaxation time for the calcite I-II transition estimated by Wang and Meltzer. 12 


\section{References}

1. D. E. Grady, R. E. Hollenbach, and K. W. Schuler, Compression Wave Studies on Calcite Rock, J. Geophys. Res., 83, 2839-2848, 1978.

2. D. E. Grady, Interrelation of Flow or Fracture and Phase Transition in the Deformation of Carbonate Rock, J. Geophys. Res., 84, 7549-7554, 1979.

3. K. W. Schuler and D. E. Grady, Compression Wave Studies in Solenhofen Limestone, SAND76-0279, Sandia National Laboratories, Albuquerque, NM, (May 1977).

4. D. E. Grady, Stress-Wave Studies in Selected Crystal Rocks, Sandia National Lahoratories Report (in preparation).

5. D. E. Grady, R. E. Hollenbach, K. W. Schuler, and J. F. Callender, Strain Rate Dependence in Dolomite Inferred from Impact and Static Compression Studies, J. Geophys. Res., 82, 1325-1333, 1977.

6. D. E. Grady and R. E. Hollenbach, Impact Studies on Tonopah Test Range Welded Tuff, SAND76-0104, Sandia National Laboratories, Albuquerque, NM (June 1976).

7. L. M. Barker and R. E. Hollenbach, Laser Interferometry for Measuring High Velocities of Any Reflecting Surface, J. Appl. Phys., 43, 4669, 1972 .

8. D. E. Grady and E. G. Young, Evaluation of Constitutive Properties from Velocity Interferometer Data, SAND75-0650, Sandia National Laboratories, Albuquerque, NM (August 1976).

9. W. J. Murri, D. E. Grady, and K. D. Mahrer, Equation of state of Rock, Stanford Research Institute Report, July 1975.

10. L. M. Barker, VISAR Data Reduction, SLA-73-1038, Sandia National Laboratories, Albuquerque, NM (1974).

11. D. E. Grady, Coherent Phase Transformation Under Nonhydrostatic StressWave Loading, J. Geophys. Res. (submitted).

12. C. Wang and M. Meltzer, Ultrasonic Study of Phase Transition in Calcite to 20 K.ilobars and $180^{\circ} \mathrm{C}, \mathrm{J}$. Geophyc. Rce. 78, 1293-1298, 1073. 
Distribution

C. K. B. Lee

R\&D Associates

P. O. Box 9695

Marina Del Rey, CA 90291

T. J. Ahrens

California Institute of Technology Pasadena, CA 91109

D. R. Curran

Stanford Research Institute

333 Ravenswood Avenue

Menlo Park, CA 94025

G. Duvall

Dept. of Physics

Washington State University

Pullman, WA 99163
H. C. Heard

Lawrence Livermore Laboratory

P. O. Box 808

Livermore, CA 94550

C. Petersen

Systems, science \& Software

P. O. Box 1620

La Jolla, CA 92038

L. G. Margolin

Los Alamos National Laboratory

Los Alamos, NM 87545

R. J. Clifton

Dept. of Engineering

Brown University

Providence, RI 02912

R. Jeànloz

Dept. of Geology and Geophysics

University of California

Berkeley, C.A 94720
1500
W. Herrmann
1510
D. B. Hayes
152n T. B. Iane
1522 K. W. Schuler
1530 L. W. Davison
1531 B. J. Thorne
1532 P. Y. Yarrington
1533 T. K. Bergstresser
1533 M. E. Kipp
1533
1534
1534
1534
1534
1534
1534
1534
1540
1542
1542
8214
3141
3151
J. W. Swegle
J. R. Asay
L. M. Barker
L. Chhabildas
D. S. Drumheller
D. E. Grady (25)
T. G. Irucano
ร. L. W1se
W. C. Luth
B. M. Butcher
L. S. Costin
M. A. Pound
L. J. Erickson (5)
W. L. Garner (3)

FOR DOE/TIC

3154-4 C. Dalin (25) 


\section{DO NOT MICROFILM \\ DHIS PAGE}

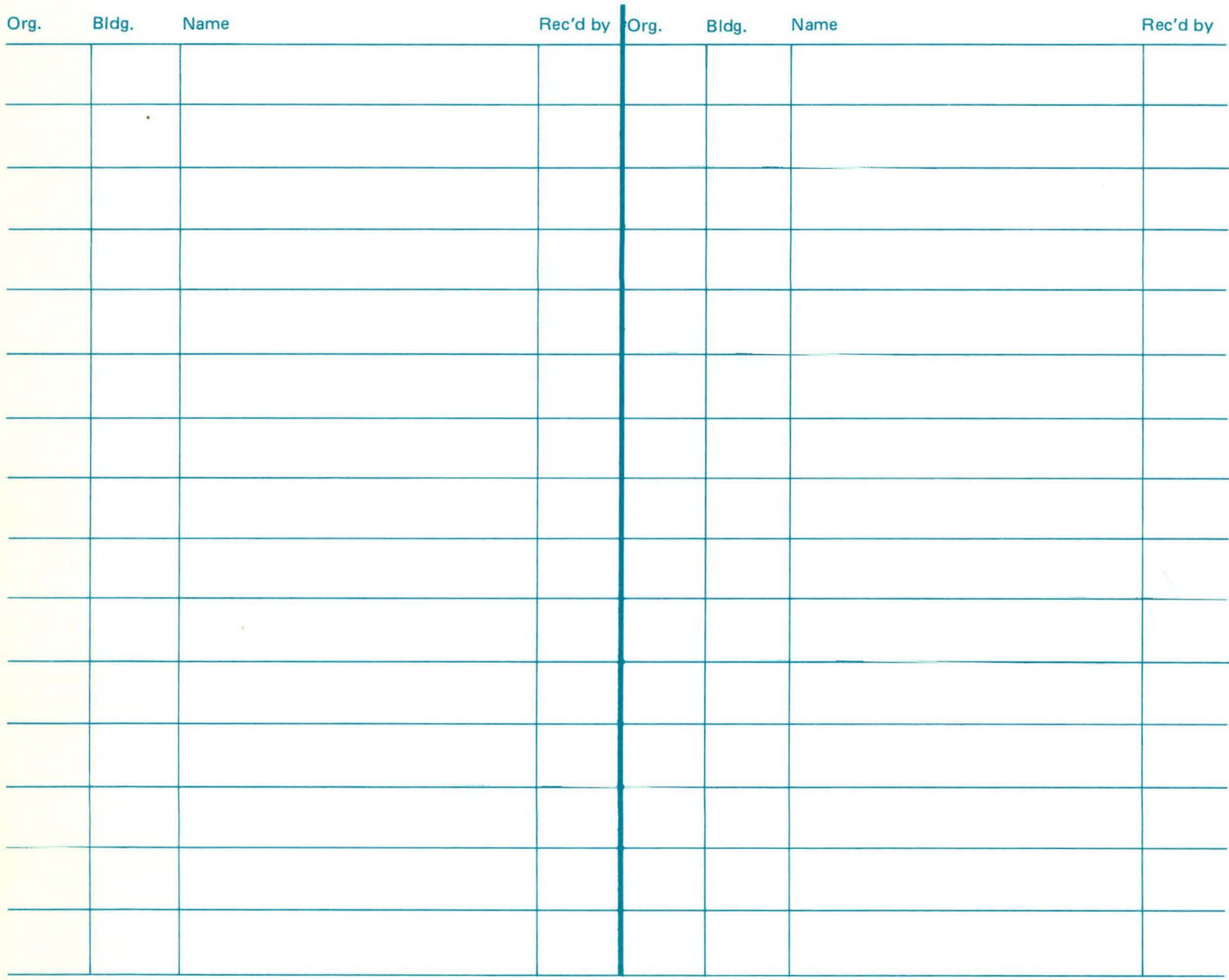

